\title{
Knowledge and attitude toward road traffic regulations among students of Health Sciences College in Taif Region, KSA
}

\author{
Ali Hassan Al-Zahrani \\ Department of Community Health, Faculty of Medicine and Applied Sciences, Taif University, Taif, KSA. \\ Correspondence to: Ali Hassan Al-Zahrani, E-mail: emadtawfik72@yahoo.com
}

Received October 28, 2014. Accepted November 10, 2014

\section{Abstract}

Background: Road traffic accidents (RTAs) are not frequently because of ignorance but are because of carelessness, thoughtlessness, and overconfidence, and it can lead to permanent disability. Hence, it is very important to determine the students' attitude and knowledge toward the road traffic regulation in Saudi Arabia.

Objectives: The objectives of this study were to assess the knowledge, attitudes, and practices of male students at the Health Science College in Taif University, Taif, KSA, toward road traffic regulations.

Materials and Methods: This study was performed during the second semester of the academic year 2013 among the students studying at the Health Science College for Boys in Taif University, Taif, KSA. A questionnaire of 18 different questions was distributed to all available students and asked to respond under the direct supervision of the heads of the four departments of the college. The questionnaire consisted of three main parts: the first was about the sociodemographic and scientific data of the students; the second on the knowledge of road traffic regulations; and the third dealt with the attitudes of driving and the use of seat belts.

Results: One hundred twenty students participated in this study. The mean age of the participants was 21 years; $30 \%$ lived in cities, and $60 \%$ and $100 \%$ had cars and driving licenses, respectively. More than half of the students had been involved in RTAs; $83.3 \%$ of these had been injured in these RTAs and $41.6 \%$ admitted to hospital for an average of $11 \pm 1.3$ days. High speed was the main cause of their RTAs. The percentage of knowledge of road traffic regulation was moderate in more than $90 \%$ of the students, while more than $85 \%$ of them believed in the importance of the use of seat belts.

Conclusion: This study revealed that many students had been involved in RTAs as a result of driving at high speed. Most of the students had good attitude toward the use of seat belts.

KEY WORDS: Attitudes, knowledge, road traffic regulations, students

\section{Introduction}

Road traffic accidents (RTAs) are defined as fatal or nonfatal injuries incurred as a result of road traffic crashes. The crash is defined as a collision or incidence that may or may not lead to injury, occurring on a public road and involving at least one moving vehicle. ${ }^{[1]}$ Each year, more than 20 million people were injured or crippled and 1.17 million killed because

\begin{tabular}{|l|l|}
\hline Website: htp://wnw.jmsph.com & Access this article online \\
\hline DOl: 10.5455/ijmsph.2015.2810201447 & \\
\hline
\end{tabular}

of RTAs. ${ }^{[2]}$ This represents an average of 3,242 persons dying each day worldwide. In addition to these deaths, between 20 and 50 million people globally are estimated to be injured or disabled every year. ${ }^{[1]}$

Accidents are not frequently because of ignorance but are because of carelessness, thoughtlessness, and overconfidence. Robertson// and researchers from Road Safety Agency in the USA have pointed out that road accidents were associated with numerous problems, each of which needed to be addressed separately. ${ }^{[3]}$

Reported from developed nations indicated that the use of seat belts is one of the most effective ways to reduce road accident fatalities. ${ }^{[4,5]}$ Other studies have shown that, when a road accident occurs, the use of the seat belt prevents certain types of injuries to vehicle occupants or mitigates their severity. ${ }^{[6-8]}$ Another reason for RTA is using handheld mobile telephone while driving. There is increasing evidence that the 
use of a handheld mobile telephone while driving a motor vehicle increases the risk of a traffic accident. ${ }^{[9-11]}$

Developing countries account for more than $85 \%$ of the deaths, and close to $90 \%$ of the disability are caused by road traffic crashes worldwide. ${ }^{[12]}$ In addition, rapidly increasing motorization is outpacing the development of transportation infrastructure. This fact is the primary reason for the increasing numbers and rates of motor vehicle injuries in developing countries. Other factors that contribute to the high rate of accident in less-developed countries include a high prevalence of old vehicles that often carry many people than they are often designed to carry, lack of safety belt, poor road design and maintenance, and the traffic mix on roads. ${ }^{[13]}$

No previous studies are available regarding the knowledge and attitude toward the road traffic regulation in Taif, KSA. Therefore, the objectives of this study were to determine the knowledge and attitudes and the factors influencing RTA of university students in Taif, KSA.

\section{Material and Methods}

This study was conducted for more than 5 months from October to June of the academic year 2013 among the students of Health Science College, Taif University, Taif, KSA. The data were collected through the use of a questionnaire, which consisted of three parts, namely, sociodemographic, knowledge, and attitude. The questionnaire contained 19 questions. It was adopted from a previous study conducted in Saudi Arabia. ${ }^{[14]}$ It was distributed randomly to the students of the Faculty of Health Sciences through the lecturers in four different departments, namely: Medical Laboratory, Nursing, Physical Therapy, and Radiology. This was completed under the direct supervision of each lecturer of the departments who returned them to the investigator.

For the attitude, the following scoring system was followed: convinced about the importance of seat belt: 1 = very weak, 2 = weak, 3 = strong, and $4=$ very strong; insistence on passengers' use of seat belt: $1=$ never, 2 = sometimes, $3=$ usually, and $4=$ always; reasons that make you use seat belt: 4 = I like to comply with regulation, $3=$ I am convinced of importance of the use of seat belt, $2=$ seat belt has become compulsory practice, and $1=$ it is civilization phenomenon; difficulties you face when you use seat belt: 1 = restriction of movement, 2 = anxiety, 3 = forgetfulness/others, and $4=$ no difficulties; effect of using seat belt: $1=$ no effect on the rate of disabilities, 2 = reduce rate and complications of RTA, $3=$ reduce disabilities caused by RTA, and $4=$ reduce the incidence of RTAs; reason for using seat belt: $4=$ drivers are convinced of the importance of using seat belt, $3=$ positive impact of health education conducted by traffic road departments, 2 = drivers are afraid of punishment, and 1 = others.

For the purpose of this study, high knowledge and positive attitude were considered desirable attributes of the participants with higher compliance to road traffic regulations. Data were analyzed using the Statistical Package for Social
Table 1: Sociodemographic characteristics and previous RTA-related events of the students participated in the current study $(n=120)$

\begin{tabular}{|c|c|}
\hline Item & N. $(\%)$ \\
\hline Age (year) & $21 \pm 1.6$ \\
\hline \multicolumn{2}{|l|}{ Place of residence } \\
\hline City & $50(41.6)$ \\
\hline Village & $65(54.1)$ \\
\hline Desert & $5(4.1)$ \\
\hline Missing & $0(0)$ \\
\hline \multicolumn{2}{|l|}{ Department } \\
\hline Laboratory & $40(33.3)$ \\
\hline Nursing & $40(33.3)$ \\
\hline Physical Therapy & $17(14.1)$ \\
\hline Radiology & $23(19.2)$ \\
\hline Missing & $0(0)$ \\
\hline \multicolumn{2}{|l|}{ Own a car } \\
\hline Yes & $72(60)$ \\
\hline No & $48(40)$ \\
\hline \multicolumn{2}{|l|}{ Has a driving license } \\
\hline Yes & $120(100)$ \\
\hline No & $0(0)$ \\
\hline \multicolumn{2}{|l|}{ Exposure to previous RTA } \\
\hline Yes & $60(50)$ \\
\hline 1 RTA & $20(33.3)$ \\
\hline 2 RTAs & $18(30)$ \\
\hline 3 RTAs & $14(23.3)$ \\
\hline$>3$ RTAs & $8(13.3)$ \\
\hline No & $60(50)$ \\
\hline \multicolumn{2}{|l|}{ Injured in these RTAs } \\
\hline Yes & $50 / 60(83.3)$ \\
\hline No & $10 / 60(16.6)$ \\
\hline \multicolumn{2}{|l|}{ Admission to hospital } \\
\hline Yes & $50 / 120(41.6)$ \\
\hline No & $70 / 120(59.4)$ \\
\hline Average hospital stay (in days) & $11 \pm 1.3$ \\
\hline \multicolumn{2}{|l|}{ Reasons for previous RTA } \\
\hline High speed & $60 / 120(50)$ \\
\hline Overtaking another car & $21 / 120(17.5)$ \\
\hline More than one reason & $10 / 120(8.3)$ \\
\hline Others & $9 / 120(7.5)$ \\
\hline \multicolumn{2}{|c|}{ Death in family resulting from RTA in past 10 years } \\
\hline Yes & $22(18.3)$ \\
\hline No & $196(81.6)$ \\
\hline Total number of deaths & 100 \\
\hline
\end{tabular}

Sciences Software (SPSS) version 13. T-tests were performed to analyze the univariate analysis.

\section{Results}

The total number of the participants in this study was 120 students from the Faculty of Health Sciences, Taif University, Taif, KSA. The mean age of the participant was 
Table 2: Knowledge of students concerning road traffic regulations and RTAs

\begin{tabular}{lc}
\hline Knowledge & $\mathbf{n}=\mathbf{1 2 0}$ \\
\hline Degree of knowledge about road traffic regulation on laws \\
High & $15(12.5)$ \\
Moderate & $90(75)$ \\
Low & $15(12.5)$ \\
The most important reasons for RTA & $60(50)$ \\
High speed alone & $8(6.6)$ \\
Drivers' lack of awareness of traffic regulations & $12(10)$ \\
$\quad$ and laws alone & \\
Drivers' noncompliance with traffic rules and & \\
$\quad$ regulations alone & $30(66.6)$ \\
All the above reasons & $30(25)$ \\
More than one reason
\end{tabular}

$21 \pm 1.6$ years, minimum 18 years, and maximum was 23 years. Less than half of the participants, $50(41.6 \%)$, lived in the city. The majority of the students were from the Laboratory and Nursing Department, $80(66.6 \%)$. All of them, $120(100 \%)$, had a driving license. However, only $72(60 \%)$ of them owned cars. Sixty students $(50 \%)$ had not been involved in RTA. However, $50(83.3 \%)$ students have been injured in the RTAs, and the average hospital stay was $11 \pm 1.3$ days. High speed was the major cause of these RTAs $(50 \%)$. The number of deaths resulting from the RTA in the past 10 years was 22 $(18.3 \%)$ [Table 1].

The majority of the participants, $90(75 \%)$, mentioned that they had moderate knowledge about road traffic regulations, and most of them, $80(66.6 \%)$, mentioned that high speed, drivers' lack of awareness about traffic regulation and laws, and drivers' noncompliance high with traffic rules and regulation were the most important cause of RTAs [Table 2].

When the participants were asked about the importance of the use of seat belt, about 102 students (85\%) were very strongly/strongly convinced of its importance. However, on the reasons for using seat belts, 72 students $(60 \%)$ felt convinced of its use, followed by 24 students $(20 \%)$ as seat belt has become compulsory practice, 10 participants liked to comply with regulations $(8.3 \%)$, and then seat belt is a civilized phenomenon for 4 participants (3.3\%). Forgetfulness and restriction of movement represent the majority of causes regarding difficulties the student face when using the seat belt $(79.1 \%)$. Majority of the students $(58.3 \%)$ have the opinion that seat belts have the ability to reduce the rate and complications of RTAs, and the major reason for using the seat belt was that the drivers were afraid of punishment (59.16\%) [Table 3].

\section{Discussion}

It is generally accepted that vehicle crashes cannot be prevented completely but that some of the injuries and severity can be prevented or minimized by simple protective ways such
Table 3: Attitudes of students concerning road traffic regulations and RTAs

\begin{tabular}{|c|c|}
\hline Attitudes & $n=120$ \\
\hline \multicolumn{2}{|l|}{ Convinced about the importance of seat belts } \\
\hline Very strong & $102(85)$ \\
\hline Strong & $8(6.6)$ \\
\hline Weak/very weak & $10(8.3)$ \\
\hline \multicolumn{2}{|l|}{ Insistence on passengers' use of seat belts } \\
\hline Always & $5(4.16)$ \\
\hline Sometimes & $40(33.3)$ \\
\hline Usually & $40(33.3)$ \\
\hline Rarely/never & $10(8.3)$ \\
\hline Not respond & $25(20.8)$ \\
\hline \multicolumn{2}{|l|}{ Reasons that make you use seat belt } \\
\hline I like to comply with regulations & $10(8.3)$ \\
\hline I am convinced of importance of the use of seat belt & $72(60)$ \\
\hline Seat belt has become compulsory practice & $24(20)$ \\
\hline It is civilized phenomenon & $4(3.3)$ \\
\hline More than one reason & $10(8.3)$ \\
\hline No response & $0(0)$ \\
\hline \multicolumn{2}{|l|}{ Difficulties you face when you use seat belt } \\
\hline Restriction of movement & $45(37.5)$ \\
\hline Anxiety & $10(8.3)$ \\
\hline Forgetfulness & $50(41.6)$ \\
\hline Others & $5(4.16)$ \\
\hline No difficulties & $10(8.3)$ \\
\hline No response & $0(0)$ \\
\hline \multicolumn{2}{|l|}{ Effects of using the seat belt } \\
\hline Reduce the incidence of RTA & $30(25)$ \\
\hline Reduce disabilities caused by RTA & $10(8.3)$ \\
\hline Reduce rate and complications of RTA & $70(58.3)$ \\
\hline No effect on the rate of disabilities & $10(8.3)$ \\
\hline No response & $0(0)$ \\
\hline \multicolumn{2}{|l|}{ Reason for using the seat belt } \\
\hline Drivers are afraid of punishment & $71(59.16)$ \\
\hline $\begin{array}{l}\text { Drivers are convinced of the importance of } \\
\text { using seat belt }\end{array}$ & $22(18.3)$ \\
\hline $\begin{array}{l}\text { Positive impact of health education conducted by } \\
\text { traffic road departments }\end{array}$ & $10(8.3)$ \\
\hline More than one reason & $17(14.16)$ \\
\hline No response & $0(0)$ \\
\hline
\end{tabular}

as using seat belts for car users. Many factors cause RTAs, such as car conditions, driver's attitude, and the road conditions. The objective of this study was to determine the knowledge and attitudes toward road traffic regulation among the students in Health Sciences College, Taif University, KSA.

Majority of the students had cars $(60 \%)$, perhaps, because most of the Saudi families have cars. Findings were similar to those reported by Al-Khaldi. ${ }^{[15]}$. One hundred percent of the students had driving licenses, and this is because all the students were above the legal age for owning a driver's license in Saudi Arabia (18 years or older). These findings were different to those reported by Redhwan and Karim. ${ }^{[16]}$ 
Most of the students had been involved in RTAs, which had resulted in 50 of them being injured with 50 admissions for $11 \pm 1.3$ days on the average. The main reason for these RTAs was high speed (50\%). These findings were similar to those reported by many other investigators. ${ }^{[14,17]}$ About $18.3 \%$ of the students mentioned that they had lost at least one relative in a RTA in the previous 10 years. This means that, as reported by Ansari et al., ${ }^{[14]}$ the Saudi society has a major problem with RTAs.

Our study has showed that the majority of the students have good knowledge about road traffic regulations. However, in the absence of comprehensive test of this part in the study, this response has to be viewed with caution. Most of the students mentioned that high speed was the most common reason for RTAs. These findings were in accord with what had been reported in previous studies. ${ }^{[18]}$

In our study, it was obvious that the students was convinced about the importance of the use of seat belts $(85 \%)$ and its impact on the rate and complications of disability from RTAs $(58.3 \%)$. However, many students used seat belts because of their fear of punishment resulting from noncompliance. These facts indicate that the obligatory use of seat belts was a step in the right direction. The use of seat belts increased among the students as a result of the legislation $(59.16 \%)$. These findings are higher than those reported from the USA, different provinces in Saudi Arabia, and some Gulf states. ${ }^{[19,20]}$

\section{Conclusion}

This study revealed that many students had been involved in RTAs as a result of overspeeding. Most students knew the road traffic rules and understood the importance of the use of seat belts. The use of seat belts had increased after the legislation, but there are still problems with compliance because of the negative attitudes. This can only be addressed with aggressive enforcement of the regulation by the road traffic police.

\section{References}

1. World Health Organization. Report on Injuries and Violence Prevention: Road Traffic Injuries. Geneva, Switxerland: WHO, 2002.

2. Binder S, Runge JW. Road safety and public health: a US perspective and the global challenge. Inj Prev. 2004;10:68-9.

3. Johnston I. Action to reduce road casualties. World Health Forum. 1992;13:154-62.
4. Green RN, German A, Nowak ES, Dalmotas D, Stewart DE. Fatal injuries to restrained passenger car occupants in Canada: crash modes and kinematics of injury. Accid Anal Prev. 1994;26:207-14.

5. Evans L. Safety-belt effectiveness: the influence of crash severity and selective recruitment. Accid Anal Prev. 1996;28:423-33.

6. Arajärvi E. A retrospective analysis of chest injuries in 280 seat belt wearers. Accid Anal Prev. 1988;20:251-9.

7. Campbell BJ, Stewart JR, Reinfurt DW. Change in injuries associated with safety belt laws. Accid Anal Prev. 1991;23:87-93.

8. Shibata A, Fukuda K. Risk factors of fatality in motor vehicle traffic accidents. Accid Anal Prev. 1994;26:391-7.

9. Lamble D, Kauranen T, Laakso M, Summala H. Cognitive load and detection thresholds in car following situations: safety implications for using mobile (cellular) telephones while driving. Accid Anal Prev. 1999;31:617-23.

10. Violanti JM. Cellular phones and traffic accidents. Public Health. 1997:111:423-8.

11. Violanti JM. Cellular phones and fatal traffic collisions. Accid Anal Prev. 1998;30:519-24.

12. Krug EG, Sharma GK, Lozano R. The global burden of injuries. Am J Public Health. 2000;90:523-6.

13. Odero W, Garner P, Zwi A. Road traffic injuries in developing countries: a comprehensive review of epidemiological studies. Trop Med Int Health. 1997;2:445-60.

14. Ansari S, Akhdar F, Mandoorah M, Moutaery K. Causes and effects of road traffic accidents in Saudi Arabia. Public Health. 2000;114:37-9.

15. Al-Khaldi YM. Attitude and practice towards road traffic regulations among students of health sciences college in aseer region. J Family Community Med. 2006;13:109-13.

16. Redhwan A, Karim A. Knowledge, attitude and practice towards road traffic regulations among university students, Malaysia. Int Med J Malaysia. 2010;9:29-34.

17. Badawi IA, Alakija W, Aziz MA. Road traffic accidents in Asir region, Saudi Arabia: pattern and prevention. Saudi Med J. 1995;16:257-60.

18. Nofal FH, Saeed AA, Anokute CC. Aetiological factors contributing to road traffic accidents in Riyadh City, Saudi Arabia. J R Soc Health. 1996;116:304-11.

19. Pace BW, Thailer R, Kwiatkowski TG. New York State mandatory seatbelt use law: patterns of seatbelt use before and after legislation. J Trauma. 1986;26:1031-3.

20. Mufti MH. Medico-legal aspects of seat belt legislation in Saudi Arabia. Saudi Med J. 1986;7:84-90.

How to cite this article: Al-Zahrani $\mathrm{AH}$. Knowledge and attitude toward road traffic regulations among students of Health Sciences College in Taif Region, KSA. Int J Med Sci Public Health 2015;4: 241-244

Source of Support: Nil, Conflict of Interest: None declared. 